\title{
Burden of Liver Cirrhosis in Portugal between 2010 and 2017
}

\author{
João Manuel Silva ${ }^{a}$ Mário Jorge Silva ${ }^{b, c}$ Filipe Calinas $^{b}$ \\ Paulo Jorge Nogueira ${ }^{d-g}$
}

${ }^{a}$ Centro Hospitalar Universitário Cova da Beira, Covilhã, Portugal; ${ }^{b}$ Centro Hospitalar Universitário de Lisboa Central,

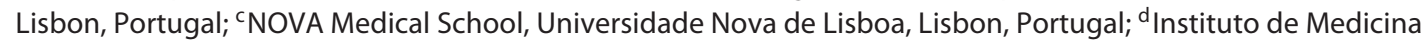
Preventiva e Saúde Pública, Faculdade de Medicina, Universidade de Lisboa, Lisbon, Portugal; ' Instituto de Saúde Ambiental (ISAMB), Faculdade de Medicina, Universidade de Lisboa, Lisbon, Portugal; f Public Health Research Centre, NOVA National School of Public Health, Universidade Nova de Lisboa, Lisbon, Portugal; ${ }^{9}$ Comprehensive Health Research Center (CHRC), NOVA National School of Public Health, Universidade Nova de Lisboa, Lisbon, Portugal

\section{Keywords}

Burden · Cirrhosis · Alcoholic liver disease · Hepatitis B virus . Hepatitis C virus

\section{Abstract}

Introduction: Liver cirrhosis is a prevalent disease in Portugal. Recent changes in alcohol consumption, as well as the wide use of direct-acting antivirals for hepatitis C since 2015, may be contributing to changes in the national burden of liver cirrhosis in the last few years. Objectives: We aim to characterize the burden of cirrhosis in Portugal between 2010 and 2017. Patients and Methods: We analyzed all hospital admission episodes due to cirrhosis in Portugal Mainland between 2010 and 2017, registered in the national Diagnosis-Related Group database, according to etiology of cirrhosis. We also analyzed data on mortality and potential years of life lost from liver cirrhosis and chronic liver disease, retrieved from Statistics Portugal (National Institute for Statistics). Results: Between 2010 and 2017, a total of 51,438 admissions for liver cirrhosis occurred in Portugal. The annual number of admissions decreased ( $p=0.044$ ) during the analyzed period. The most frequent cause of cirrhosis was alcoholic liver disease, present in $78.9 \%$ of all admissions ( $n=40,595)$, followed by chronic hepatitis C virus infection, present in $11.3 \%(n=5,823)$. A male predominance was identified in the admissions for every analyzed cause of cirrhosis. Annual admissions for alcoholic cirrhosis remained stable ( $p=0.075$ ) during the 8-year period. The same stable tendency was observed in the number of admissions for cirrhosis caused by hepatitis $C$ virus $(p=0.861)$ and alcohol plus hepatitis $C$ virus infection ( $p=0.082$ ), although these admissions for hepatitis C-related cirrhosis increased until 20142015 and steadily decreased thereafter. Annual deaths due to liver cirrhosis and chronic liver disease decreased from 1,357 in 2010 to 1,038 in 2017 ( $p=0.002$ ). The number of potential years of life lost decreased as well in the period ( $p=$ 0.001). Conclusion: The burden of cirrhosis, evaluated by hospital admissions, mortality, and potential years of life lost, decreased in Portugal between 2010 and 2017.

(c) 2020 Sociedade Portuguesa de Gastrenterologia Published by S. Karger AG, Basel

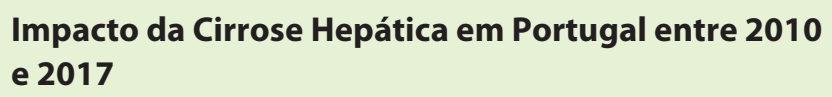

(C) 2020 Sociedade Portuguesa de Gastrenterologia Published by S. Karger AG, Basel

This article is licensed under the Creative Commons AttributionNonCommercial-NoDerivatives 4.0 International License (CC BY NC-ND) (http://www.karger.com/Services/OpenAccessLicense). Usage and distribution for commercial purposes as well as any distribution of modified material requires written permission.
João Manuel Simão Silva

Department of Internal Medicine

Centro Hospitalar Universitário Cova da Beira

Quinta do Alvito, PT-6200-251 Covilhã (Portugal)

joaomsilva71@gmail.com 


\section{Resumo}

Introdução: A cirrose hepática é uma patologia prevalente em Portugal. Alterações recentes no consumo de álcool, assim como o uso generalizado de antivíricos de ação direta para a hepatite $C$ desde 2015, podem estar a contribuir para alterações no peso nacional da cirrose hepática nos últimos anos. Objetivos: Pretendemos caracterizar o impacto da cirrose em Portugal entre 2010 e 2017. Doentes e Métodos: Analisámos todos os episódios de internamento hospitalar por cirrose em Portugal Continental entre 2010 e 2017, registados na base de dados dos Grupo de Diagnósticos Homogéneos, de acordo com a etiologia da cirrose. Também analisámos dados de mortalidade e anos de vida potencialmente perdidos por cirrose e doença hepática crónica, disponibilizados pelo Instituto Nacional de Estatística. Resultados: Entre 2010 e 2017 ocorreram 51438 internamentos por cirrose hepática em Portugal. O número total de internamentos diminuiu ( $p=0,044$ ) durante o período analisado. A causa mais frequente de cirrose foi doença hepática alcoólica, presente em $78,9 \%$ de todos os internamentos ( $n=$ 40 595), seguido da infeção crónica pelo vírus da hepatite C, presente em 11,3\% $(n=5823)$. Verificou-se predominância de doentes do género masculino em todas as causas de cirrose analisadas. $O$ número de internamentos anual por cirrose alcoólica manteve-se estável $(p=0,075)$ durante os 8 anos. A mesma tendência foi observada no número de internamentos por infeção por vírus de hepatite $C(p=0,861)$ e álcool mais infeção por vírus de hepatite $C(p=0,082)$ - embora estes internamentos por cirrose relacionada com hepatite $C$ tenham aumentado até 2014-2015 e depois diminuído sustentadamente. O número anual de óbitos por cirrose e doença hepática crónica diminuiu de 1357 em 2010 para 1038 em 2017 $(p=0,002)$. O número de anos potenciais de vida perdidos diminuiu também ( $p=0,001)$ nesse período. Conclusão: O impacto da cirrose, avaliado através dos internamentos hospitalares, mortalidade e anos potenciais de vida perdidos, diminuiu em Portugal entre 2010 e 2017.

C 2020 Sociedade Portuguesa de Gastrenterologia Publicado por S. Karger AG, Basel

\section{Introduction}

Liver diseases account annually for approximately 2 million deaths worldwide [1-3], most of them potentially preventable [1]. Together, cirrhosis and liver neoplasms were responsible for $3.5 \%$ of all deaths worldwide in 2015 $[2,3]$, and the number has been increasing [2]. Liver cir- rhosis alone accounts for more than 1 million deaths per year $[1,2]$, being the 11th cause of death [2] and the fourth cause of disability-adjusted life years in the world [1].

Europe has the largest burden of liver disease in the world [4], with an estimated prevalence of 26.0 cases per 100,000 inhabitants [3]. In Europe, alcoholic liver disease is the major cause of cirrhosis-associated death (9.2 deaths per 100,000 inhabitants), followed by hepatitis $C$ virus infection (5.3/100,000 inhabitants) and hepatitis B virus infection (3.9/100,0000 inhabitants) [5].

In Portugal, liver cirrhosis and chronic liver disease accounted for $0.9 \%$ of all deaths occurring in $2017(1.5 \%$ of deaths among males and $0.4 \%$ of deaths among females) [6]. The most common cause of liver cirrhosis is alcoholic liver disease, which was responsible for $63-84 \%$ of hospital admissions for liver disease or liver cirrhosis in 3 nationwide studies on data from 1993-2012 [7-9]. Hepatitis C-related liver disease was a common and increasing cause of cirrhosis, at least until recently: admissions for hepatitis C-related liver cirrhosis rose about $50 \%$ between 2003 and 2012 [9].

Some recent factors may have been changing the epidemiology of liver cirrhosis in Portugal in the last few years. Alcohol consumption has been decreasing [10]. In 2015, Portugal was one of the first countries in the world to approve universal access to direct-acting antivirals for hepatitis C [11], during the first years preferentially for patients with advanced disease, with over 18,000 patients with treatment authorized between 2015 and 2017 [12]. Nonetheless, a possible impact on the national burden of liver disease has not been evaluated yet.

An ongoing monitorization of the epidemiology of liver disease in Portugal is essential both to evaluate implemented policies and to identify areas in need for further projects.

\section{Objective}

The objective of this study was to characterize the burden of liver cirrhosis in Portugal between 2010 and 2017, as evaluated by hospital admissions, mortality, and potential years of life lost.

\section{Patients and Methods}

We separately evaluated hospital admissions for liver cirrhosis, and mortality and potential years of live lost for liver cirrhosis and chronic liver disease in the present descriptive study. Data on hospital admissions were extracted (on 15th November 2019) from the Diagnosis-Related Group database from the Portuguese Health System's Central Administration, a national database where all 
Table 1. Number and tendency of annual hospital admissions for liver between 2010 and 2017

\begin{tabular}{|c|c|c|c|c|c|c|c|c|c|c|}
\hline Etiology of cirrhosis & 2010 & 2011 & 2012 & 2013 & 2014 & 2015 & 2016 & 2017 & Total & $\begin{array}{l}\text { Tendency } \\
2010-2017(p)\end{array}$ \\
\hline Alcohol & 4,695 & 5,435 & 4,820 & 4,551 & 4,096 & 3,996 & 4,325 & 4,433 & 36,351 & Stable $(p=0.075)$ \\
\hline $\mathrm{HCV}$ & 248 & 306 & 315 & 285 & 402 & 424 & 313 & 206 & 2,499 & Stable $(p=0.861)$ \\
\hline $\mathrm{HCV}+$ alcohol & 286 & 342 & 395 & 413 & 513 & 464 & 411 & 413 & 3,237 & Stable $(p=0.082)$ \\
\hline $\mathrm{HBV}$ & 77 & 91 & 71 & 64 & 54 & 64 & 42 & 60 & 523 & Reduction $(p=0.023)$ \\
\hline Total admissions & 6,399 & 7,217 & 6,748 & 6,544 & 6,166 & 6,123 & 6,146 & 6,095 & 51,438 & Reduction $(p=0.044)$ \\
\hline
\end{tabular}

$\mathrm{HBV}$, hepatitis B virus; HCV, hepatitis C virus.

discharge diagnoses from public hospitals in Portugal Mainland are registered. Admissions at public hospitals represent the vast majority of admissions in the country $(78.9 \%$ of all admissions in Portugal in 2012) [13]. Codifications completed up to December 2016 were registered according to the International Classification of Diseases, Ninth Revision, Clinical Modification (ICD-9-CM) [14], and from 1st January 2017 onwards (irrespective of discharge date) are registered according to the Tenth Revision of ICD [15, 16]. For every admission, data on patient demographics, type of admission, length of stay, outcome, main diagnosis, and up to 19 secondary diagnoses are collected.

We selected all admissions for liver cirrhosis, from patients aged 20 years or older, between 2010 and 2017. To specifically retrieve admissions in which the main diagnosis was cirrhosis (and not those where cirrhosis was a concurrent secondary disease), we selected admissions whose main diagnosis was cirrhosis itself, or whose main diagnosis was a complication of cirrhosis with a concomitant secondary diagnosis suggestive of cirrhosis. Specific codes were selected after a review of several coded admissions, and possible correspondences between ICD-9-CM and ICD-10 codes were extensively reviewed.

Codifications defining cirrhosis as the main diagnosis were alcoholic cirrhosis, biliary cirrhosis, and other cirrhosis of the liver (codes $571.2,571.6$ or 571.5 in ICD-9-CM or K70.3, K74.3, K74.4, K74.5 or K74.6 in ICD-10).

Complication of cirrhosis was defined as either one of the following: hepatic encephalopathy (codes 572.2 or 348.3 in ICD-9CM or K72.9, K70.41 or G93.4 in ICD-10), portal hypertension (codes 572.3 in ICD-9-CM or K76.6 in ICD-10), esophageal varices (codes $456.0,456.1$ or 456.2 in ICD-9-CM or I85 or I86.4 in ICD-10), ascites (codes 789.59 in ICD-9-CM or R18 in ICD-10), spontaneous bacterial peritonitis (codes 567.23 in ICD-9-CM or K65.2 in ICD-10), hepatorenal syndrome (codes 572.4 in ICD-9CM or K76.7 in ICD-10), unspecified pleural effusion (codes 511.9 or 511.89 in ICD-9-CM or J90, J91.8 or J94.8 in ICD-10), jaundice (codes 782.4 in ICD-9-CM or R17 in ICD-10), alcoholic hepatitis (codes 571.1 in ICD-9-CM or K70.1 or K70.4 in ICD-10), other sequelae of chronic liver disease/chronic liver failure (codes 572.8 in ICD-9-CM or K72.1 or K72.9 in ICD-10), acute/subacute necrosis/failure of the liver (codes 570 in ICD-9-CM or K72.0 in ICD-10), or primary liver neoplasm/liver cell carcinoma (codes 155.0 in ICD-9-CM or C220 in ICD-10).

Burden of Cirrhosis in Portugal
Codifications defining cirrhosis as a secondary diagnosis (in admissions whose main diagnosis was a complication of cirrhosis) were chronic liver disease/failure (codes $571.8,571.9$ or 572.8 in ICD-9-CM or K70.2, K70.4, K70.9, K72.1, K72.9, K74.0, K74.2 or K76.9 in ICD-10) and chronic hepatitis (codes 571.4 in ICD-9-CM or K73, K75.2, K75.3, K75.4, K75.8, K75.9 in ICD-10).

Cirrhosis was classified according to etiology considering alcoholic liver disease, hepatitis B, and hepatitis C. We have allowed single or multiple causes for cirrhosis. For example, alcoholic cirrhosis was defined in the presence of alcoholic liver disease and the absence of chronic hepatitis $\mathrm{B}$ or $\mathrm{C}$. If both chronic hepatitis $\mathrm{C}$ and alcoholic liver disease were present (in the absence of chronic hepatitis $\mathrm{B}$ ), cirrhosis was presumed to be caused by both hepatitis $\mathrm{C}$ and alcohol.

Codifications defining cause of cirrhosis were alcoholic liver disease (codes 571.0, 571.1, 571.2 and 571.3 in ICD-9-CM or K70.0, K70.1, K70.2, K70.4, K70.3 or K70.9 in ICD-10), chronic hepatitis B (codes $070.22,070.23,070.32,070.33$ or V02.61 in ICD9-CM and B18.0, B18.1, B19.1 or Z22.51 in ICD-10), and chronic hepatitis C (codes $070.44,070.54,070.7$ or V02.62 in ICD-9-CM or B18.2, B19.2 or Z22.52 in ICD-10). Other causes of cirrhosis were not considered in the analysis.

Data on mortality and potential years of life lost were retrieved from the National Institute for Statistics (Statistics Portugal), both from the online available metainformation and from annual reports. Available data are on liver cirrhosis and chronic liver disease in aggregation.

Statistical analysis was carried out using Microsoft Office Excel $^{\circledR} 2010$ (Microsoft Corporation ${ }^{\circledR}$, Redmond, WA, USA), IBM SPSS Statistics $21^{\circledR}\left(\right.$ IBM $^{\circledR}$ Corporation, Armonk, NY, USA) and R Statistical Software for Windows ${ }^{\circledR}$ (R Foundation ${ }^{\circledR}$, Vienna, Austria). A $p$ value less than 0.05 (two-sided) was considered statistically significant. Test of time trends were performed using linear regression with time as an independent variable.

\section{Results}

\section{Hospital Admissions for Liver Cirrhosis (All Causes)}

Between 2010 and 2017, there were a total of 51,438 hospital admission episodes for liver cirrhosis in Portu- 
Fig. 1. Annual hospital admissions for liver cirrhosis between 2010 and 2017, by cirrhosis etiology. Total number of admissions decreased $(p=0.044)$. Admissions for alcoholic cirrhosis remained stable $(p=$ 0.075). Annual admissions for cirrhosis due to hepatitis $C(p=0.861)$ and hepatitis C plus alcohol $(p=0.082)$ remained stable. Admissions for cirrhosis due to hepatitis B decreased ( $p=0.023)$, but admissions for cirrhosis due to hepatitis B plus alcohol remained stable $(p=0.393)$. Admissions for cirrhosis due to both hepatitis B and hepatitis C remained stable $(p=0.395)$ (Diagnosis-Related Group database).

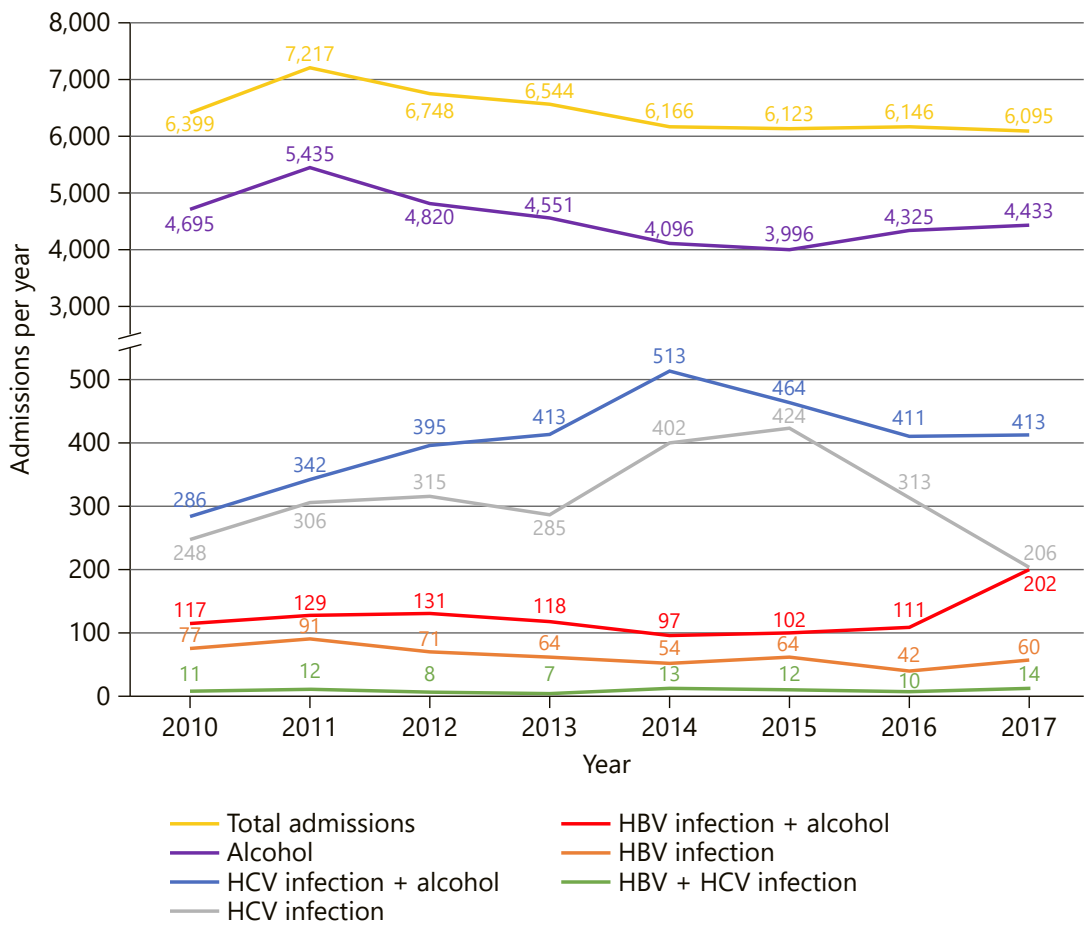

gal, $77.7 \%(n=39,967 / 51,438)$ corresponding to male patients. A cause of cirrhosis was identified in $85.0 \%(n=$ $43,704 / 51,438)$ of admissions. The most frequent cause was alcoholic liver disease, followed by chronic infection by hepatitis $C$ virus and chronic infection by hepatitis $B$ virus. The annual number of admissions for liver cirrhosis from all causes decreased significantly $(p=0.044)$ over the 8-year period, although this tendency was not observed in most etiologies when analyzed independently. Annual number and longitudinal trends of hospital admissions according to etiology of cirrhosis and year are detailed in Table 1 and Figure 1.

\section{Cirrhosis due to Alcoholic Liver Disease}

Alcoholic liver disease was the single most common cause of admission for cirrhosis in Portugal between 2010 and 2017. Alcoholic cirrhosis alone, without concomitant hepatitis B or C, accounted for $70.7 \%(n=36,351)$ of all admissionepisodesintheperiod, $82.2 \%(n=29,898 / 36,351)$ of them corresponding to male patients. Globally, the number of annual admissions due to alcoholic cirrhosis remained stable $(p=0.075)$ during the 8 -year observation period, ranging from 5,435 admissions in 2011 to 3,996 admissions in 2015. The largest number of annual admissions due to alcoholic cirrhosis was observed in 2011.
Furthermore, alcoholic liver disease was an etiological co-factor of liver cirrhosis in $55.6 \%$ of admissions for hepatitis $\mathrm{C}$ virus-related liver disease $(n=3,237 / 5,823)$ and in $62.3 \%$ of admissions for hepatitis B virus-related liver disease $(n=1,007 / 1,617)$. Indeed, either alone or associated with a viral etiology, alcoholic liver disease was present in $78.9 \%$ of all admissions ( $n=40,595 / 51,438)$, as shown in Table 1 and Figure 1.

\section{Cirrhosis due to Chronic Infection by Hepatitis $C$ Virus}

Chronic infection by hepatitis $\mathrm{C}$ virus is a major cause of cirrhosis in Portugal and was present in $11.3 \%(n=$ $5,823 / 51,438)$ of all admission episodes for liver cirrhosis, $81.3 \%$ ( $n=4,736 / 5,823)$ of them corresponding to male patients. Among those admissions, only $42.9 \%$ ( $n=$ $2,499 / 5,823)$ corresponded to chronic hepatitis C alone; in $55.6 \%(n=3,237 / 5,823)$ there was concomitant alcoholic liver disease, and in $1.5 \%(n=87 / 5,823)$ hepatitis $\mathrm{B}$ virus was present as an etiological cofactor.

Considering the patients with cirrhosis due to hepatitis $C$ virus infection alone, the annual number of admissions remained globally stable between 2010 and 2017 $(p=0.861)$. But in detail, the annual number of admissions increased from 248 in 2010 to 424 in 2015 and then 
Fig. 2. Annual mortality due to cirrhosis and chronic liver disease between 2010 and 2017 , per patient gender $[6,13,17-21]$.

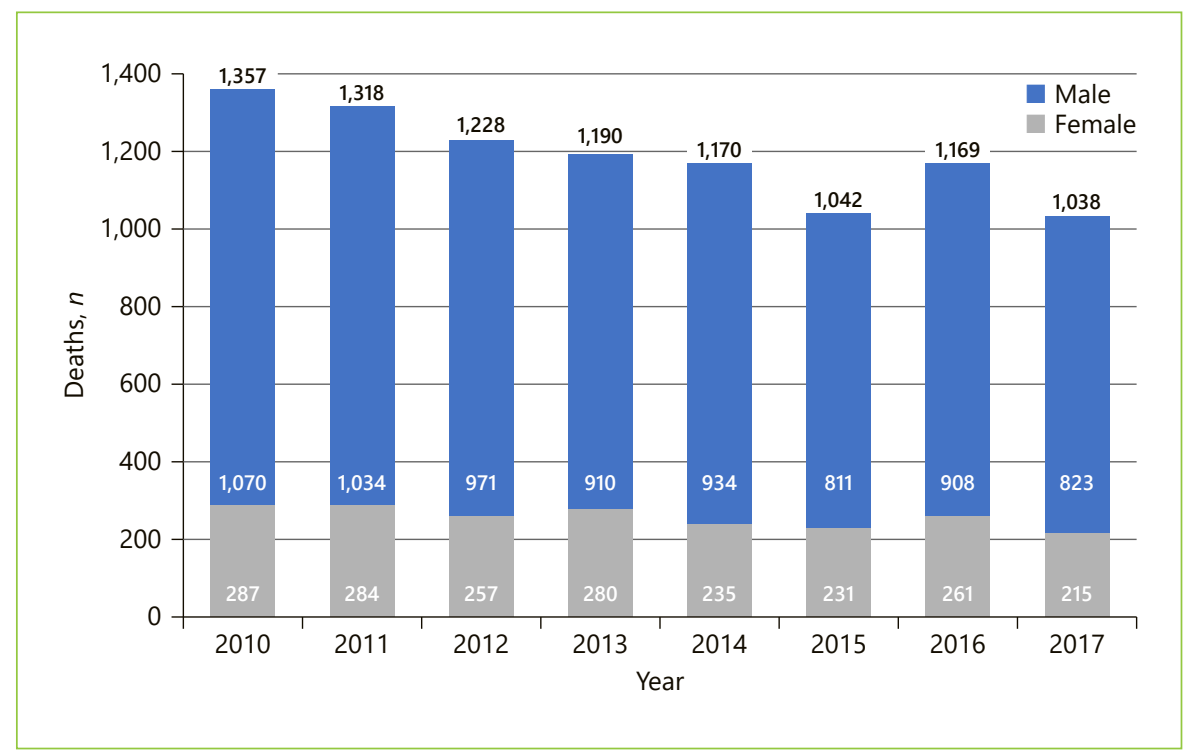

Table 2. Annual death rate of liver cirrhosis, per 100,000 inhabitants [13]

\begin{tabular}{lrrrrrrrr}
\hline Gender & 2010 & 2011 & 2012 & 2013 & 2014 & 2015 & 2016 & 2017 \\
\hline Male & 20.8 & 20.5 & 19.4 & 18.3 & 18.9 & 16.5 & 18.6 & 16.9 \\
Female & 5.2 & 5.1 & 4.7 & 5.1 & 4.3 & 4.2 & 4.8 & 4.0 \\
\hline Total & $\mathbf{1 2 . 8}$ & $\mathbf{1 2 . 5}$ & $\mathbf{1 1 . 7}$ & $\mathbf{1 1 . 4}$ & $\mathbf{1 1 . 2}$ & $\mathbf{1 0 . 1}$ & $\mathbf{1 1 . 3}$ & $\mathbf{1 0 . 1}$ \\
\hline
\end{tabular}

rapidly decreased to a minimum of 206 in 2017. Similar trends are observed in hospital admissions for cirrhosis due to hepatitis $\mathrm{C}$ plus alcoholic liver disease, with an inversion point in 2014 (Table 1; Fig. 1). Recall that wide availability of direct-acting antivirals for hepatitis $\mathrm{C}$ was initiated in 2015 [11].

\section{Cirrhosis due to Chronic Infection by Hepatitis $B$ Virus}

Admissions for hepatitis B-related cirrhosis accounted for 3.1\% $(n=1,617 / 51,438)$ of admission episodes for cirrhosis between 2010 and 2017, 81.8\% $(n=1,322 / 1,617)$ corresponding to male patients. In most cases, a concomitant cause of liver cirrhosis was present: in $62.3 \%(n=$ $1,007 / 1,617)$ alcoholic liver disease and in 5.4\% $(n=$ $87 / 1,617)$ concomitant infection by hepatitis $C$ virus.

Between 2010 and 2017, the number of admissions for cirrhosis due to hepatitis B decreased $(p=0.023)$ (Table 1; Fig. 1).

Burden of Cirrhosis in Portugal
Mortality and Potential Years of Life Lost due to Liver Cirrhosis and Chronic Liver Disease

Mortality due to liver cirrhosis and chronic liver disease in Portugal decreased significantly between 2010 and 2017 ( $p=0.002$ ), from a maximum of 1,357 deaths in 2010 to a minimum of 1,038 deaths in 2017 [6,13,17-21], as shown in Figure 2.

Mortality rates decreased from $12.8 / 100,000$ inhabitants in 2010 to $10.1 / 100,000$ inhabitants in 2017 [13]. Mortality rates were higher in male patients ranging from 20.8 deaths $/ 100,000$ inhabitants in 2010 to 16.9 deaths $/ 100,000$ inhabitants in 2017 . In females, the mortality rate in 2012 was 5.2 deaths/100,000 inhabitants and decreased to 4.0 deaths/100,000 inhabitants in 2017 (Table 2). Most deceased patients were aged 65-74 years [13].

In close accordance with mortality trends, the potential years of life lost due to liver cirrhosis and chronic liver disease in Portugal decreased significantly between 2010 and 2017 ( $p=0.001$ ). A maximum of 13,647 years lost were observed in 2010 , decreasing to 8,848 years lost 
Fig. 3. Annual potential years of life lost between 2010 and 2017, per patient gender [13].

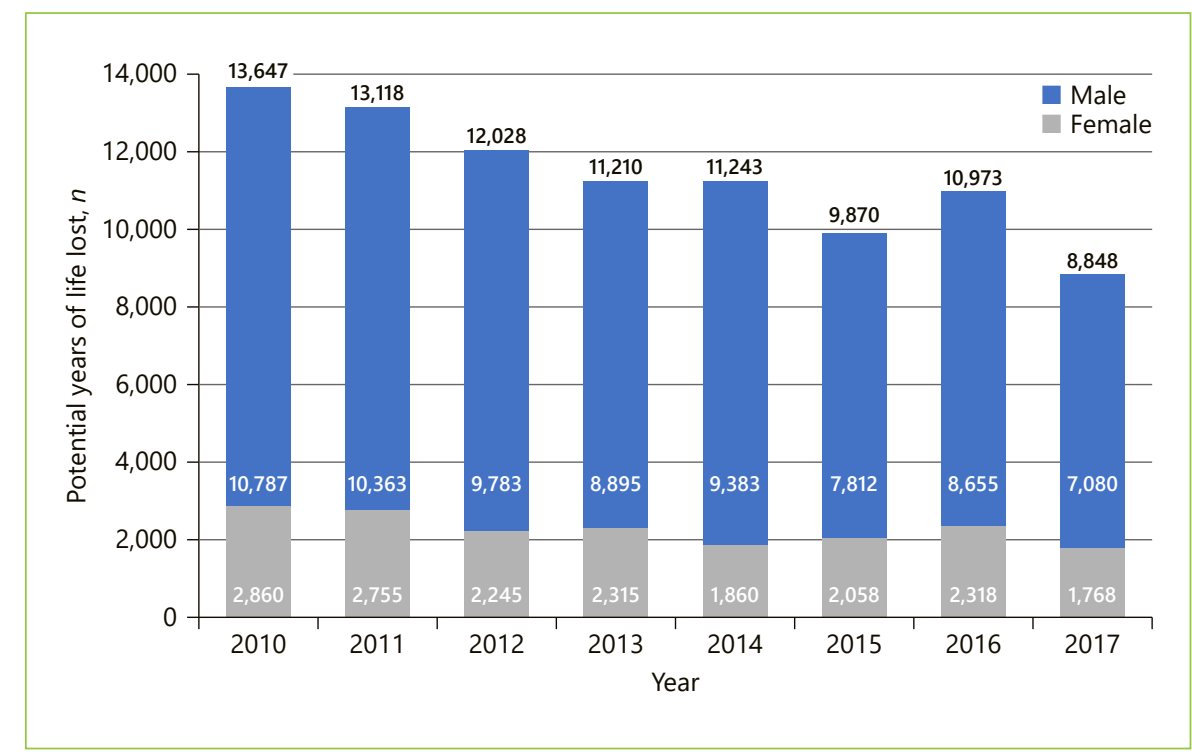

in 2017 [13]. A male prevalence was once again observed in all the evaluated years, as shown in Figure 3.

\section{Discussion}

We observed a significant decrease in the burden of liver cirrhosis in Portugal between 2010 and 2017, evaluated both by hospital admissions for liver cirrhosis and by mortality and potential years of life lost due to cirrhosis and chronic liver disease. Alcohol-related liver disease remains, by far, the major cause of liver cirrhosis in Portugal. Alcohol alone accounts for over $70 \%$ of admitted cirrhosis and is a cofactor in over $50 \%$ of cirrhosis related either to hepatitis $C$ or hepatitis $B$ virus.

Admissions for alcoholic cirrhosis remained stable during the evaluated period, even though alcohol consumption decreased in the period (13.5 L of pure alcohol/ year per capita in 2010 to $12.3 \mathrm{~L}$ /year in 2016) [10]. Alcohol beverage sales decreased between 2012 and 2015 in the country as well [10].

We may speculate on an apparent decrease in hospital admissions during the latter half of the analysis period, although statistically the number of admissions remained stable, with a possible contribution from an outlier value in 2011 that we were not able to justify.

The predominance of alcoholic cirrhosis among males is in accordance with alcohol consumption patterns: in Portugal, consumption per capita is much higher among men (20.5 L pure alcohol/year) than among women (5.1 L/year) (data from 2016) [10].
Chronic hepatitis $\mathrm{C}$ is an important cause of liver disease in the world. In the European Union, there was an estimated prevalence of more than 3.2 million infected patients in 2015 [22, 23] and 342,243 deaths in 2017 [5, 24]. In Portugal, seroprevalence for hepatitis $C$ was estimated to range from 0.46 to $1.5 \%$ [25-27]. Estimates for the whole Portuguese population are frail and difficult to obtain as infection tends to cluster in high-risk groups, such as people who use drugs, whose seroprevalence is higher $59 \%$ in individuals undergoing treatment for drug abuse, and over $80 \%$ among people who inject drugs) [28-30].

Continuing a rising trend since 2003 that we already described in a previous work [9], we observed an increase in annual admissions for hepatitis C-related cirrhosis (either alone or associated with alcoholic liver disease) until $2014-2015$, followed by a steady decrease thereafter. The short period of observation does not allow for an absolute conviction, but those are encouraging data suggesting a decrease in the burden of hepatitis C-related liver disease in the country since 2014-2015.

In fact, since 2015, there is universal access to directacting antivirals for treatment of hepatitis $\mathrm{C}$ in the country. Although all patients with hepatitis $C$ virus infection are eligible nowadays to start therapy with direct-acting antivirals, during the first 2 years priority was given to patients with advanced liver disease (F3/F4) and a few other prioritizing factors [31]. The successful treatment of patients with more advanced disease was expected to prevent decompensation [32-34] with impact already in the short term $[35,36]$. 
Up to December 2015, 8,650 treatments were authorized, $57.3 \%(n=4,954 / 8,650)$ of them for patients with advanced liver fibrosis or cirrhosis (F3/F4). Since 2016, the proportion of treated patients with lower grades of fibrosis has been increasing. Up to June 2018, a total of 20,367 treatments were started, about one half of them $-45.5 \%(n=$ $9,256 / 20,367)$ - for patients with advanced fibrosis and cirrhosis [37]. Up to January 2020, 24,926 patients started treatment, with a cure rate of $96.5 \%(n=15,200 / 15,755)$ : over 15,200 patients were cured in 5 years [38].

Each successful hepatitis $C$ treatment means individual liver-related and non-liver-related benefits for the treated patient, including reductions/benefits in liver stiffness, portal hypertension, risk of decompensation, hospitalizations, incidence of hepatocellular carcinoma, need for liver transplant, extrahepatic manifestations, liver-related and all-cause mortality [33-36, 39]. But furthermore, each hepatitis $\mathrm{C}$ cure contributes to lower disease transmission in the population [39], ultimately promoting a decrease in incidence and prevalence of the disease [40-42].

A favorable cost-effectiveness of direct-acting antivirals was anticipated [43] and has been confirmed [44]. Our results suggest a decreasing burden of hepatitis Crelated liver disease in Portugal, as has been recently described in Spain until 2015 [45]. Further monitorization of epidemiology of hepatitis C in Portugal is needed for more solid interpretations.

The burden of admitted hepatitis B-related cirrhosis is low. The present results are generally overlapping with a previous observation, where hepatitis B virus accounted for $2.9 \%$ of all cirrhosis-related admissions between 2003 and 2012 [9]. The prevalence of hepatitis B in Portugal is low and has been decreasing in the last decades (HBsAg prevalence was $1.13-2.0 \%$ in studies carried out in 1980 1989 and $0.02-1.45 \%$ in studies carried out in 1990-2014, although higher in some population subgroups [46]), probably reflecting the efficacy of vaccination programs adopted in Portugal since 1994 [28] and the access to antiviral therapies. Furthermore, long-term treatment with nucleos(t)ide analogues induces cirrhosis regression [47] and reduces the risk of decompensation and hepatocellular carcinoma $[2,3]$, allowing the vast majority of these patients to be followed up on an ambulatory basis without need for hospital admissions.

The decrease in mortality and, accordingly, in the years of potential life lost is encouraging and corroborates a decreasing burden of liver cirrhosis in Portugal during this 8-year period. In fact, a decrease in mortality due to liver cirrhosis in Portugal has been observed at least since the 1980 s (e.g., in 1986, there were 2,953 deaths due to liver cirrhosis in the country, corresponding to mortality rates of 43.2/100,000 inhabitants among men and 17.2/100,000 inhabitants among women) [13].

The present results contribute to an update on the burden of liver cirrhosis in Portugal in the last few years. Analysis of hospital admissions was based on a prior report from our team [9]. Data on the overlapping years (2010-2012) are similar although not exactly equal, in our opinion essentially due to updates of the databases that occurred in the meanwhile. Aware of this limitation, and as the most recent data are more susceptible to updating, we decided not to consider data corresponding to 2018 (data extraction from database performed on 2019). We highlight that the burden of hospital admissions was analyzed through the number of admission episodes, rather than the number of admitted patients, and, therefore, direct extrapolation of prevalences of the different causes of cirrhosis is hampered.

Another potential limitation is the transition in codification of the admissions database, from ICD-9-CM to ICD-10, for codifications performed from 1st January 2017 onwards. In order to minimize this potential susceptibility, we performed an extensive review of both ICD-9 and ICD-10 codes to establish the best possible correspondences for each ICD-9-CM code.

As every coding-based report, results are directly dependent on the correct codification of the admission files, which may be suboptimal [9]. Furthermore, there is no specific code for viral hepatitis $[9,48,49]$, which may therefore be underreported. At last, we only considered 3 causes of liver cirrhosis, impairing the analysis of other causes of liver disease, including non-alcoholic fatty liver disease (which was not analyzed as it lacks a specific code in ICD-9-CM).

Nonetheless, and keeping these limitations in mind, we believe that the present results are solid and credible. We are also convinced that the analysis of longitudinal trends is not severely affected by possible defective reporting as these errors are not expected to change over time. Nevertheless, continuing analysis in Portugal as well as similar studies in other countries, particularly in southern Europe, are needed.

\section{Conclusion}

There was a significant reduction in the overall burden of liver cirrhosis in Portugal between 2010 and 2017, evaluated by the decrease in hospital admissions and, more 
importantly, by the decreasing mortality and of potential years of life lost.

During the analyzed period, reduction in alcohol consumption was not followed by a significant decrease in alcohol-related cirrhosis admissions. On the other hand, there was an apparent decrease of hepatitis C-related admissions after the wide availability of direct-acting antivirals. Admissions for hepatitis B cirrhosis also decreased during the evaluated period.

\section{Statement of Ethics}

Ethical and legal principles were followed according to the Declaration of Helsinki.

\section{Conflict of Interest Statement}

The authors have no conflicts of interest to declare.

\section{Funding Sources}

This work was produced with the support of INCD funded by FCT and FEDER under the project 01/SAICT/2016 No. 022153.

\section{Author Contributions}

J.M.S. and M.J.S. designed and wrote the article. P.J.N. contributed to data and statistical analysis. F.C. reviewed the manuscript. All authors approved the final version to be published.

\section{References}

1 Rowe IA. Lessons from Epidemiology: The Burden of Liver Disease. Dig Dis. 2017;35(4): 304-9.

2 Asrani SK, Devarbhavi H, Eaton J, Kamath PS. Burden of liver diseases in the world. J Hepatol. 2019 Jan;70(1):151-71.

3 Moon AM, Singal AG, Tapper EB. Contemporary Epidemiology of Chronic Liver Disease and Cirrhosis. Clin Gastroenterol Hepatol. 2019 Aug;S1542-3565(19)30849-3

4 Pimpin L, Cortez-Pinto H, Negro F, Corbould E, Lazarus JV, Webber L, et al.; EASL HEPAHEALTH Steering Committee. Burden of liver disease in Europe: epidemiology and analysis of risk factors to identify prevention policies. J Hepatol. 2018 Sep;69(3):718-35.

5 Global Burden of Disease Study 2017 (GBD) Results [Internet]. Institute for Health Metrics and Evaluation. [cited 2020 Mar 2]. Available from: http://www.healthdata.org/gbd

6 Instituto Nacional de Estatística IP. Causas de Morte - 2017. Lisboa, Portugal; 2019.

7 Cortez-Pinto H, Marques-Vidal P, Monteiro E. Liver disease-related admissions in Portugal: clinical and demographic pattern. Eur J Gastroenterol Hepatol. 2004 Sep;16(9):8737.

8 Marinho RT, Duarte H, Gíria J, Nunes J, Ferreira A, Velosa J. The burden of alcoholism in fifteen years of cirrhosis hospital admissions in Portugal. Liver Int. 2015 Mar;35(3):74655.

9 Silva MJ, Rosa MV, Nogueira PJ, Calinas F. Ten years of hospital admissions for liver cirrhosis in Portugal. Eur J Gastroenterol Hepatol. 2015 Nov;27(11):1320-6.

10 Serviço de Intervenção nos Comportamentos Aditivos e nas Dependências (SICAD). Relatório Anual 2018 - A Situação do País em Matéria de Álcool. Lisboa, Portugal; 2019.

11 Velosa J, Macedo G. Elimination of Hepatitis C in Portugal: An Urban Legend?. GE Port J Gastroenterol. 2020 Apr;27(3):166-71.
12 Roseira MB. O estado da saúde em Portugal [Internet]. 2018. Available from: http://www. scielo.mec.pt/pdf/egg/v13n1/v13n1a09.pdf

13 Instituto Nacional de Estatística IP [Internet]. Indicators database. [cited 2020 Mar 1]. Available from: https://www.ine.pt/xportal/ xmain?xpid=INE\&\%23x0026;xpgid \&\%23x0 03D;ine_base_dados

14 Centers for Disease Control and Prevention [Internet]. International Classification of Diseases, Ninth Revision, Clinical Modification [ICD-9-CM] 2011 edition. [cited 2020 Feb 5]. Available from: http://www.cdc.gov/nchs/ icd $/$ icd $9 \mathrm{~cm} . h \mathrm{htm}$

15 ACSS - Administração Central do Sistema de Saúde [Internet]. Codificação Clínica. [cited 2020 Feb 5]. Available from: http://www.acss. min-saude.pt/2016/07/22/portal-da-codificacao-3/

16 Centers for Medicare \& Medicaid Services [Internet]. 2016 ICD-10-CM and GEMs [cited 2020 Feb 5]. Available from: https://www. $\mathrm{cms}$.gov/Medicare/Coding/ICD10/2016ICD-10-CM-and-GEMs

17 Instituto Nacional de Estatística IP. Risco de Morrer - 2012. Lisboa, Portugal; 2013.

18 Instituto Nacional de Estatística IP. Causas de Morte - 2013. Lisboa, Portugal; 2015.

19 Instituto Nacional de Estatística IP. Causas de Morte - 2014. Lisboa, Portugal; 2016.

20 Instituto Nacional de Estatística IP. Causas de Morte - 2015. Lisboa, Portugal; 2017.

21 Instituto Nacional de Estatística IP. Causas de Morte - 2016. Lisboa, Portugal; 2018.

22 Razavi H, Robbins S, Zeuzem S, Negro F, Buti M, Duberg AS, et al.; European Union HCV Collaborators. Hepatitis $\mathrm{C}$ virus prevalence and level of intervention required to achieve the WHO targets for elimination in the European Union by 2030: a modelling study. Lancet Gastroenterol Hepatol. 2017 May;2(5): $325-36$.
23 Chen Q, Ayer T, Bethea E, Kanwal F, Wang X, Roberts $\mathrm{M}$, et al. Changes in hepatitis $\mathrm{C}$ burden and treatment trends in Europe during the era of direct-acting antivirals: a modelling study. BMJ Open. 2019 Jun;9(6):e026726.

24 Sepanlou SG, Safiri S, Bisignano C, Ikuta KS, Merat S, Saberifiroozi M, et al.; GBD 2017 Cirrhosis Collaborators. The global, regional, and national burden of cirrhosis by cause in 195 countries and territories, 1990-2017: a systematic analysis for the Global Burden of Disease Study 2017. Lancet Gastroenterol Hepatol. 2020 Mar;5(3):245-66.

25 Santos A, Carvalho A, Bento D, Sá R, Tomaz J, Rodrigues V, et al. Epidemiologia da hepatite $\mathrm{C}$ na região centro de Portugal. Prevalência do anti-VHC na população do distrito de Coimbra. Acta Med Port. 1993 Dec;6(12): $567-72$.

26 Marinho RT, Moura MC, Giria JA, Ferrinho $\mathrm{P}$. Epidemiological aspects of hepatitis $\mathrm{C}$ in Portugal. J Gastroenterol Hepatol. 2001 Sep; 16(9):1076-7.

27 Carvalhana SC, Leitão J, Alves AC, Bourbon $\mathrm{M}$, Cortez-Pinto H. Hepatitis B and C prevalence in Portugal: disparity between the general population and high-risk groups. Eur J Gastroenterol Hepatol. 2016 Jun;28(6):640-

28 Fernandes A, Martins HC, Aldir I, Bettencourt J, Rodrigues J, Aleixo MJ, et al. Programa Nacional para as Hepatites Virais. Lisboa, Portugal; 2019.

29 European Monitoring Centre for Drugs and Drug Addiction (EMCDDA). Portugal Country Drug Report 2019. Lisboa, Portugal; 2019.

30 Serviço de Intervenção nos Comportamentos Aditivos e nas Dependências (SICAD). Relatório Anual 2017 A Situação do País em Matéria de Drogas e Toxicodependências. Lisboa, Portugal; 2018. 
31 Direção-Geral da Saúde. Norma da DireçãoGeral de Saúde 11/2012 - Tratamento da Hepatite C Crónica no Adulto. 2012. p. 1-13.

32 Pawlotsky JM, Aghemo A, Dusheiko G, Forns X, Puoti M, Sarrazin C; European Association for Study of Liver. EASL Recommendations on Treatment of Hepatitis C 2015. J Hepatol. 2015 Jul;63(1):199-236.

33 van der Meer AJ, Veldt BJ, Feld JJ, Wedemeyer H, Dufour JF, Lammert F, et al. Association between sustained virological response and all-cause mortality among patients with chronic hepatitis $\mathrm{C}$ and advanced hepatic fibrosis. JAMA. 2012 Dec;308(24):2584-93.

34 Backus LI, Boothroyd DB, Phillips BR, Belperio $\mathrm{P}$, Halloran J, Mole LA. A sustained virologic response reduces risk of all-cause mortality in patients with hepatitis C. Clin Gastroenterol Hepatol. 2011 Jun;9(6):509-516.e1.

35 Carrat F, Fontaine H, Dorival C, Simony M, Diallo A, Hezode C, et al.; French ANRS CO22 Hepather cohort. Clinical outcomes in patients with chronic hepatitis $\mathrm{C}$ after directacting antiviral treatment: a prospective cohort study. Lancet. 2019 Apr;393(10179): 1453-64.

36 McCombs J, Matsuda T, Tonnu-Mihara I, Saab S, Hines P, L'italien G, et al. The risk of long-term morbidity and mortality in patients with chronic hepatitis C: results from an analysis of data from a Department of Veterans Affairs Clinical Registry. JAMA Intern Med. 2014 Feb;174(2):204-12.

37 Assessoria de Imprensa do Infarmed IP. Comunicado de Imprensa - Dia Mundial das Hepatites. 2018.

38 Infarmed IP. Hepatite C - Monitorização dos tratamentos. 2020

39 Marinho RT, Vitor S, Velosa J. Benefits of curing hepatitis $\mathrm{C}$ infection. J Gastrointestin Liver Dis. 2014 Mar;23(1):85-90.

40 Ioannou GN, Feld JJ. What Are the Benefits of a Sustained Virologic Response to DirectActing Antiviral Therapy for Hepatitis C Virus Infection? Gastroenterology. 2019 Jan; 156(2):446-460.e2.

41 Martin NK, Vickerman P, Grebely J, Hellard M, Hutchinson SJ, Lima VD, et al. Hepatitis C virus treatment for prevention among people who inject drugs: modeling treatment scaleup in the age of direct-acting antivirals. Hepatology. 2013 Nov;58(5):1598-609.

42 Lombardi A, Mondelli MU; ESCMID Study Group for Viral Hepatitis (ESGVH). Hepatitis C: is eradication possible? Liver Int. 2019 Mar;39(3):416-26.

43 Infarmed IP. Relatório de Avaliação do Pedido de Comparticipação de Medicamento para Uso Humano: ledipasvir + sofosbuvir. 2014. Available from: https://www.in- farmed.pt/documents/15786/1437513/ledispasvir_sofosbuvir_harvoni_parecer net_20150218.pdf/e7bedcd6-6cfc-453da9de-113f99ab3472

44 Esteves BA. The Portuguese universal access program to direct-acting antivirals (Sovaldi ${ }^{\circledR}$ and Harvoni ${ }^{\circledR}$ ) for the treatment of Hepatitis C: A financial analysis of the first 2 years. Universidade Católica Portuguesa; 2017.

45 Mate-Cano I, Alvaro-Meca A, Ryan P, Resino S, Briz V. Epidemiological trend of hepatitis C-related liver events in Spain (2000-2015): A nationwide population-based study. Eur J Intern Med. 2020 May;75:84-92.

46 Silva MJ, Valente J, Capela T, Russo P, Calinas F. Epidemiology of hepatitis B in Portugal. Eur J Gastroenterol Hepatol. 2017 Mar;29(3): 249-58.

47 Marcellin P, Gane E, Buti M, Afdhal N, Sievert W, Jacobson IM, et al. Regression of cirrhosis during treatment with tenofovir disoproxil fumarate for chronic hepatitis B: a 5-year open-label follow-up study. Lancet. $2013 \mathrm{Feb}$; 381(9865):468-75.

$48 \mathrm{Kim}$ WR. The burden of hepatitis $\mathrm{C}$ in the United States. Hepatology. 2002 Nov;36(5 Suppl 1):S30-4.

49 Vong S, Bell BP. Chronic liver disease mortality in the United States, 1990-1998. Hepatology. 2004 Feb;39(2):476-83. 